\title{
The Kynurenine Pathway: A Primary Resistance Mechanism in Patients with Glioblastoma
}

\author{
PETER P. SORDILLO ${ }^{1,2}$, LAURA A. SORDILLO ${ }^{1}$ and LAWRENCE HELSON ${ }^{1}$ \\ ${ }^{1}$ SignPath Pharma, Inc., Quakertown, PA, U.S.A.; \\ ${ }^{2}$ Department of Hematology and Oncology, Lenox Hill Hospital, New York, NY, U.S.A.
}

\begin{abstract}
The failure of chemotherapy and radiation therapy to achieve long-term remission or cure in patients with glioblastoma (GBM) is, in a large part, due to the suppression of the immune system induced by the tumors themselves. These tumors adapt to treatment with chemotherapy or radiation therapy by stimulating secretion of molecules that cause tryptophan metabolism to be disrupted. Indoleamine 2,3-dioxygenase (IDO) and tryptophan 2,3-dioxygenase (TDO) are produced, accelerating metabolism along the kynurenine pathway and resulting in excess levels of quinolinic acid, 3hydroxyanthranilic acid and other neurotoxic molecules. IDO and TDO also act as checkpoint molecules that suppress T-cell function. GBM is particularly associated with severe immunosuppression, and this tumor type might be thought to be the ideal candidate for checkpoint inhibitor therapy. However, treatment with checkpoint inhibitors now in clinical use for peripheral solid tumors, such as those inhibiting cytotoxic T-lymphocyte-associated protein-4 (CTLA4) or programmed cell death-1 (PD1) receptors, results in further abnormalities of tryptophan metabolism. This implies that to obtain optimal results in the treatment of GBM, one may need to add an inhibitor of the kynurenine pathway to therapy with a CTLA4 or PDI inhibitor, or use agents which can suppress multiple checkpoint molecules.
\end{abstract}

This article is freely accessible online.

Correspondence to: Peter P. Sordillo, MD, Ph.D., 51 East 82nd Street, New York, NY 10028, U.S.A. Tel: +1 2127375706, e-mail: PELDV1@gmail.com

Key Words: Glioblastoma, tryptophan, chemotherapy resistance, kynurenine, quinolinic acid, indoleamine 2,3-dioxgenase, interferon gamma, checkpoint inhibitor, review.
Glioblastoma multiforme (GBM) is a highly malignant primary brain tumor with a very poor prognosis. Median survival is 15 months. Two-year survival is less than $30 \%$ and only $5 \%$ of patients survive 5 years $(1,2)$. Genetic abnormalities, both inherited and acquired, are common, and there is a proven association of GBM with tuberous sclerosis, von Recklinghausen's disease, Lynch syndrome and Li-Fraumeni syndrome. Importantly, patients with asthma, eczema, hay fever and other allergies have as much as a $40 \%$ reduced risk of developing GBM, while patients with AIDS have an increased risk (2-4). It is well known that GBM is associated with systemic immunosuppression, and that much of this immunosuppression is caused by the GBM cells themselves (5-10). Current standard first-line treatment of GBM is surgery, if possible, followed by radiation therapy and the chemotherapy drug, temozolomide (11-13). Second-line treatment with nitrosoureas, avastin (bevacizumab), irinotecan, or combinations of some of these agents, has only minor activity, resulting in progression-free survival (PFS) of about 3-6 months and overall survival (OS) of 4-8 months (14-18). A number of new, promising treatment approaches are under investigation, but, unfortunately, none has yet proven to be an advance in GBM treatment (19-23). Additionally, the strategy of using chemotherapy in an attempt to cure GBM may be self-defeating, as chemotherapeutic agents may increase the immunosuppressive activity of GBM cells, causing recurrence $(5,24,25)$.

\section{Tryptophan Metabolites}

Tryptophan is an essential amino acid and an important precursor of serotonin, melatonin and nicotinamide adenine dinucleotide $(26,27)$. Abnormal or unbalanced tryptophan metabolism plays a role in numerous diseases, including Alzheimer's disease (28), Parkinson's disease (29), Huntington's chorea (30), psychiatric disorders (31), as well as in cardiovascular disease (32) and diabetes (33). In the brain, for example, excess levels of the tryptophan 


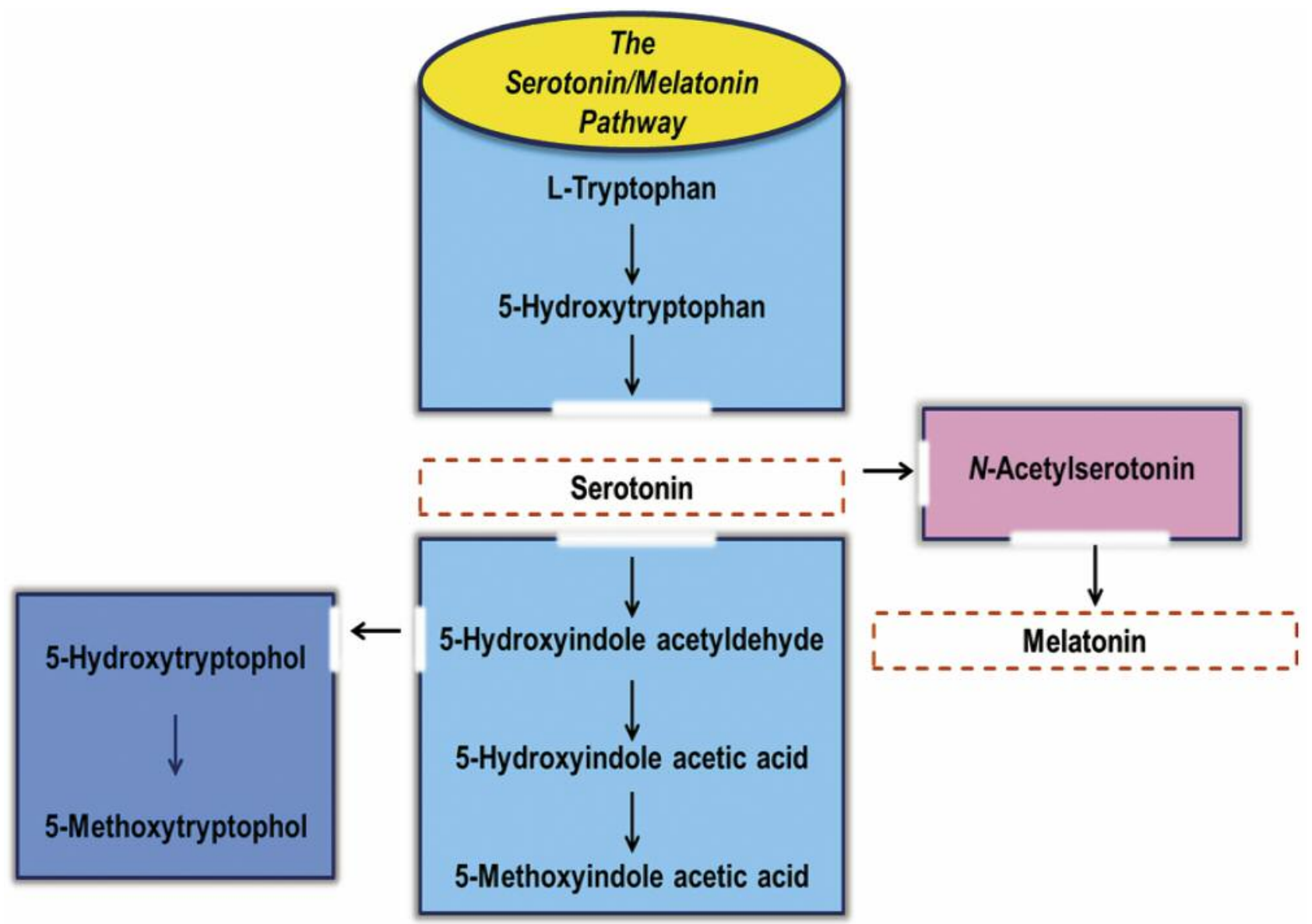

Figure 1. Tryptophan metabolism through the serotonin/melatonin pathway.

metabolite, quinolinic acid (see Figures 1 and 2), can cause neuronal death by, among other mechanisms, acting as an $\mathrm{N}$ methyl-D-aspartate (NMDA) agonist and disrupting the glutamate-glutamine cycle (34-37). Abnormal glutamate metabolism results in direct toxicity to brain cells (38-40). Quinolinic acid potentiates lipid peroxidation (37), resulting in damage to cell membranes. This metabolite also stimulates nitric acid synthase production by neurons, thus increasing free radical production $(35,37)$. Numerous other mechanisms by which quinolinic acid causes neurotoxicity have been described (41). Quinolinic acid appears to be particularly toxic to the striatum, partially explaining the role of the kynurenine pathway in both Huntington's chorea and Parkinson's disease $(36,42-44)$. Other tryptophan metabolites, including 3-hydroxykynurenine and 3hydroxyanthranilic acid, also have neurotoxic effects. Relative deficiencies of tryptophan, consistent with increased metabolism, are known to cause increased levels of ceramides and caspase-3 activation, resulting in cell apoptosis (45), and the kynurenine pathway is intimately involved in sphingolipid/ceramide metabolism (46).

Besides their neurotoxic effects, these tryptophan metabolites are known to cause cancer development and progression. Deranged tryptophan metabolism has been shown to be important in numerous types of cancer (47-52). Furthermore, the extent of the abnormality in tryptophan metabolism has been shown to correlate with the aggressiveness of the cancer (53-55). For example, Ino et al. showed that increased activity of the kynurenine pathway inversely correlated with both OS and PFS in patients with endometrial cancer (47). Heng et al. have shown that increased activity of the kynurenine pathway is associated with an unfavorable prognosis in patients with breast cancer (54). On the other hand, Sordillo et al. reported that increased tryptophan fluorescence with excitation wavelengths of 280 and $300 \mathrm{~nm}$ can distinguish cancer from adjoining normal tissue (56). Others have reported similar findings (57-59). We have also shown that increased tryptophan fluorescence 


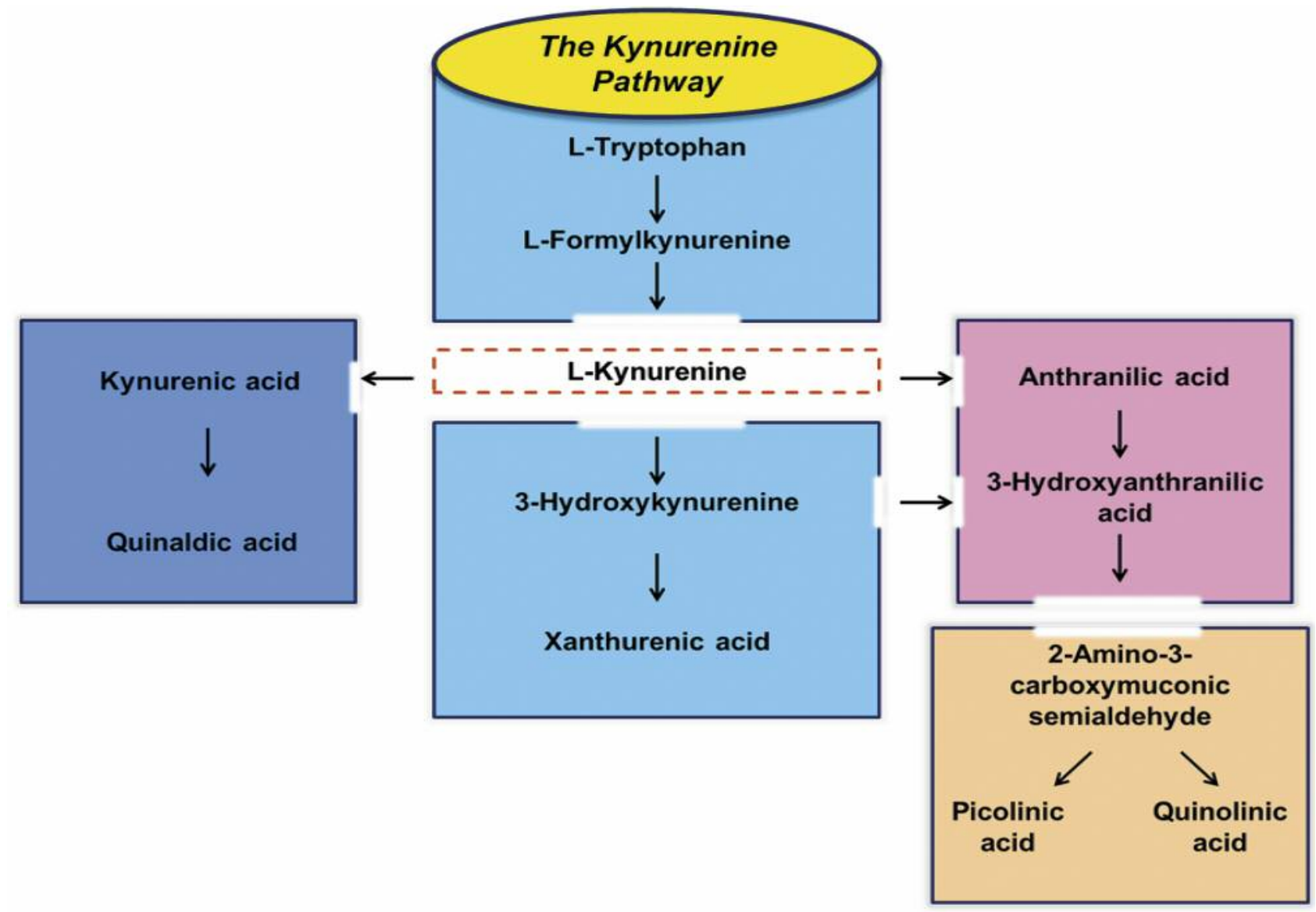

Figure 2. Tryptophan metabolism through the kynurenine pathway.

correlates strongly with increased breast cancer grade (60). $\mathrm{Pu}$ et al. reported increased tryptophan fluorescence from cell lines derived from highly aggressive prostate cancers compared to lines derived from less aggressive prostate cancers (61). Other techniques have given similar results. Zhou et al. used resonance Raman spectroscopy to show increasing tryptophan $\left(1588 \mathrm{~cm}^{-1}\right.$ mode, $532 \mathrm{~nm}$ excitation) in gliomas as the stage of these tumors increased from stage 1 to stage 4 (glioblastoma) (62). Yoracu et al. noted that it is the tryptophan buried within folded proteins, rather than exposed tryptophan, that accounts for tryptophan fluorescence (63). This may account for the consistent finding of increased tryptophan fluorescence in cancerous tissues in the face of accelerated tryptophan metabolism in patients with cancer.

\section{Pro-inflammatory Cytokines and Indoleamine 2,3-Dioxygenase}

The major cause of abnormal tryptophan metabolism in patients with GBM is an increased release of pro- inflammatory cytokines. It is well known that under stress conditions, major pro-inflammatory cytokines, such as tumor necrosis factor-alpha (TNF $\alpha$ ), interleukin-1beta (IL1 $\beta$ ), IL6 and interferon- $\gamma(\mathrm{IFN} \gamma)$ are released, both within the brain and in the periphery. Increases in these cytokines are known to be associated with many neurological conditions (64-67), as well as with many other diseases. Furthermore, high levels of these cytokines in the brain are associated with an increased severity of these diseases. For example, an elevated level of IL6 is correlated with increased mortality in patients with Parkinson's disease (65). In experimental models of Huntington's chorea, reducing levels of TNF $\alpha$ has therapeutic benefit (66). TNF $\alpha$, IL1 $\beta$, IL6, and other cytokines may be increased massively in the brain after traumatic brain injury, thousands of times more than corresponding levels in blood, and these increases are correlated with the severity of the traumatic brain injury (68). Yan et al. have shown that the degree of elevation of quinolinic acid also correlates with the degree of severity of brain injury (69). Likewise, although these pro-inflammatory 
cytokines also have anticancer effects, they are involved intimately in cancer development, progression and metastasis (70-73). Bai et al. showed that TNF $\alpha$, IL1 $\beta$ and IL6 promoted metastasis after surgery for primary hepatocellular carcinoma (70). Increased secretion of pro-inflammatory cytokines plays a particularly important role in GBM development and resistance to therapy (74-76). An important mechanism by which these cytokines cause and worsen these diseases is through of the kynurenine pathway (77-80). Campbell et al. showed that IFN $\gamma$ activates the kynurenine pathway, and TNF $\alpha$, IL1 $\beta$ and IL6 are synergistic with IFN $\gamma$ in stimulating this pathway (77). Asp et al. emphasized the important role of IFN $\gamma$ in stimulating this pathway in dermal fibroblasts (78). Zuo et al. showed that increases in inflammatory markers, and, in particular, increases in IFN $\gamma$ related inflammatory markers, correlated with increased levels of tryptophan metabolites, and also with increased mortality from neurodegenerative diseases and cancer (79). Chung and Gadupudi describe a number of ways these compounds have mutagenic properties, such as interaction with nitrites to form nitrosamine, or interaction with transition metals to form reactive oxygen species (50). Not only does abnormal glutamate metabolism caused by NDMA activity after increased production of these tryptophan metabolites result in neurotoxicity, glutamate can also act as a growth factor for cancer, which takes up this amino acid preferentially compared to normal cells (81-84).

Perhaps most importantly, metabolites of tryptophan such as quinolinic acid and 3-hydoxyanthranilic acid inhibit T-cell function, allowing tumor growth and metastasis $(54,85-89)$. Fallarino et al. showed that kynurenine metabolites, especially quinolinic acid and 3-hydroxyanthranilic acid, cause death of helper T1 (Th1) cells even at low doses, while sparing Th2 cells (85). Frumento et al. reported similar results and emphasized the important role of the enzyme indoleamine 2,3-dioxygenase (IDO) (87). As noted, this key enzyme is stimulated primarily by interferon- $\gamma(90-94)$, and interferon- $\gamma$-induced activation of IDO appears to be the critical, necessary step in the initiation of kynurenine pathway induction of immunosuppression (90). IDO is ubiquitous in tissues, and after stimulation by interferon- $\gamma$, catalyzes the first step in this pathway, the conversion of tryptophan to $\mathrm{N}$-formyl-L-kynurenine $(86,88,90,94)$. It is also widely expressed in human cancers, and its expression correlates with tumor progression and a shorter patient survival (95). As Prendergast has noted, cancers "eat" tryptophan in order to escape the immune system (53).

\section{Indoleamine 2,3-Dioxygenase and Tryptophan 2,3-Dioxygenase}

IDO is heme-containing enzyme which can degrade tryptophan by cleaving its aromatic indole ring (86). Two forms of this enzyme exist, IDO1 and IDO2. These enzymes are structurally similar, and the genes that encode them are situated next to each other on chromosome $8(86,96)$. IDO1 is expressed in a wide variety of tissues, including dendritic cells, endothelial cells, macrophages, fibroblasts and mesenchymal stromal cells, as well as in neurons and in cancer cells themselves. IDO2 is primarily expressed in the kidney, brain, colon, liver and reproductive tract (86, 95-98). IDO is critically important in inducing immune tolerance during pregnancy, and in protecting normal tissues against the immune system through its regulatory effects on T-cells (99-102). It has been shown to suppress T-lymphocytemediated graft rejection $(95,103)$. However, although this enzyme may play an important role in tumor apoptosis (93), IDO can also cause T-cell suppression after neoplastic transformation by acting as a checkpoint molecule, thus preventing the immune system from mounting an effective attack against the cancer (104-109). The local tryptophan deficiency induced by IDO stimulates the general control non-depressable-2 kinase pathway which alters protein translation and prevents T-lymphocyte activation (95). Moon et al. note that IDO inhibits activity of mechanistic target of rapamycin (mTOR), which leads to T-lymphocyte anergy (104). Other mechanisms by which IDO causes immunosuppression have been described $(95,99,104)$.

A third, distinct enzyme, tryptophan 2,3-dioxygenase (TDO), has the same effect as IDO1 and IDO2 as the initial step in the kynurenine pathway, converting L-tryptophan into $\mathrm{N}$-formyl-L-kynurenine. Like IDO, this enzyme is important in the maintenance of self-tolerance (110). TDO has been found to have a role in numerous neurological diseases, including Alzheimer's disease, Parkinson's disease and autism, and suppression of TDO appears to reduce neurodegeneration (111-114). Increased TDO activity is associated with cancer growth (115-117), as well as with increased tumor grade and decreased survival in triplenegative breast cancer cells (118).

\section{Immune Checkpoint Inhibitors: Monotherapy}

The failure of traditional approaches to have a significant impact on survival in patients with GBM suggests new strategies are necessary in the treatment of this cancer. One strategy which has had partial success against cancers other than GBM is to unleash the immune system by inhibition of immune checkpoint molecules. The most important checkpoint molecules are cytotoxic T-lymphocyte-associated protein 4 (CTLA4), programmed cell death-1 receptor (PD1) and IDO, and these checkpoint molecules are especially important in causing the profound immunosuppression associated with GBM (119-121). Grossauer et al. pointed out that all three of these checkpoint molecules are expressed at very high levels in GBM, that GBMs express much higher levels of these 
checkpoint molecules than do low-grade gliomas, and that there is a close inverse correlation of these levels with survival. These checkpoint molecules are also crucial in protecting GBM stem cells (120). Other checkpoint molecules under investigation include T-cell immunoglobulin domain and mucin domain 3 (TIM3) (122), lymphocyte activation gene-3 (LAG3) (123), killer-cell immunoglobulin-like receptor (KIR) (124) and V-domain Ig suppressor of T-cell activation (VISTA) (125). Checkpoint inhibitors are now in widespread clinical use against a wide variety of cancer types. Ipilimumab (yervoy) is a standard treatment for patients with malignant melanoma (median OS=10.1 months even in heavily pretreated patients, with some patients now having long-term survival), and is currently being investigated for the treatment of patients with non-small cell lung carcinoma $(126,127)$. The PD1 inhibitors, nivolumab (opdivo) and pembrolizumab (keytruda), and the programmed-death ligand-1 (PDL1) inhibitor atezolizumab (tecentrig), have major antitumor activity against multiple cancer types, including renal cell carcinoma, malignant melanoma, relapsed Hodgkin's disease, bladder cancer and non-small cell lung carcinoma (128-132). Nevertheless, a large majority of patients do not respond to these treatments and there can be considerable toxicity, including grade 3 and 4 pneumonitis, colitis and hepatitis in a significant number of patients.

Because of the profound immunosuppression caused by checkpoint molecules in GBM, checkpoint inhibitor therapy might be hypothesized to be the ideal type of therapy for this cancer. However, despite some promising pre-clinical results $(5,133,134)$, early studies with PD1, PDL1 or CTLA4 inhibitors against GBM have, at least as monotherapy, not yet fulfilled this promise $(120,135-139)$. Grossauer et al. noted that neither CTLA4 inhibition nor PD1 inhibition increased efficacy against GBM when used as monotherapy (120). Schaff et al. reported only stable disease or progressive disease and no major or minor responses, a median PFS of only 2.8 months and an OS of 5.1 months in patients with recurrent GBM receiving ipilimumab (135). These results are consistent with experimental data. Zeng et $a l$. studied mice implanted intracranially with GL 261 glioma cells. Mice treated with a PD1 inhibitor survived 27 days compared to controls who survived 25 days. Mice treated with a PD1 inhibitor plus radiation therapy survived 53 days (137). The less than expected activity of these inhibitors against GBM may be because, in this tumor in particular, the checkpoint inhibitor effects of these treatments are overcome by the immunosuppressive effects of other checkpoint molecules, the most important of which is IDO.

\section{Inhibitors of the Kynurenine Pathway}

Numerous IDO inhibitors are under investigation (140). Many medications and hundreds of natural products (141) also have anti-IDO activity (Tables I and II). A few studies of IDO inhibitors against GBM have been carried out and these agents do show some activity as single agents. Miyazaki et al. showed the IDO inhibitor 1-methyl L-tryptophan (1MT) prevented tryptophan consumption and suppressed the growth of LN 229 glioma cells (192). Hanihara et al. reported 1MT significantly suppressed tumor growth in a murine glioma model. 1MT also had synergistic effects with temozolomide (193). Li et al. showed that mice bearing intracranial GL 261 glioblastoma tumors that were treated with $1 \mathrm{MT}$ added to radiation therapy plus temozolomide and cytoxan, survived longer than mice treated with chemotherapy and radiation therapy alone (194). Interestingly, mice deficient in the complement component $\mathrm{C} 3$ did not experience increased survival after addition of 1MT (194). One agent, indoximod, the D-isomer of 1MT and a selective inhibitor of IDO2 (97, 195 ) is currently in clinical trials in combination with either temozolomide or bevacizumab for patients with GBM refractory to initial therapy, and a few objective responses have been seen $(196,197)$.

The importance of the kynurenine pathway as a mechanism of resistance to CTLA4 therapy has been shown in studies of other cancer types. Holmgaard et al. reported that Idoknockout mice implanted with B16F10 melanoma cells had slower tumor growth and a markedly prolonged survival compared to wild-type mice. This effect was duplicated by the addition of an IDO inhibitor to CTLA4 inhibitor therapy (198). The increased antitumor effects correlated with increased T-effector to T-regulatory (Treg) ratios in the tumors. As noted, GBM tumors secrete high levels of IDO $(119,121)$. GBMs express significantly higher IDO levels than do lowgrade gliomas, and IDO expression negatively correlates with survival (199, 200). Wainright et al. injected IDO-deficient and IDO-competent glioma cells into the cerebral hemispheres of mice, and demonstrated that the mice with IDO-deficient glioma cells survived far longer. The authors also showed that the addition of an IDO inhibitor to PD1 and CTLA4 inhibitors reversed the resistance to checkpoint inhibition, increasing $\mathrm{T}$ cell activity, reducing the number of Treg cells and extending survival in mice with GBM. This effect was not seen in mice with intracranial melanoma, suggesting IDO inhibition would be more effective in a cancer dependent on stimulation of Treg cells, such as GBM (201).

As with CTLA4 inhibitors and PD1 inhibitors, the optimal use of IDO inhibitors may be in combination with other checkpoint inhibitors to give a more complete stimulation of the immune system. Additionally, the use of agents that can inhibit more than one checkpoint molecule should be investigated. It should be remembered that although these agents inhibit multiple checkpoint molecules, they may not be potent enough in the doses received to induce responses on their own, and thus also might be optimally used in combination with other agents. 
Table I. Common medications with indoleamine 2,3-dioxygenase (IDO)-inhibitory activity.

\begin{tabular}{lcc}
\hline Drug & Comment & Reference \\
\hline Salicylates & Work by suppression of interferon gamma induction of IDO & $142,143,144,145$ \\
Indomethacin & Effect shown in human neural stem cells & 143,144 \\
Other cyclo-oxygenase-2 (COX2) inhibitors & Anticancer effects of COX2 inhibitors correlate & $146,147,148,149,150$ \\
Statins & directly with inhibition of T-regulatory cells & $151,152,153$ \\
Anti-estrogens & May also increase IDO activity through increased interleukin-10 secretion & $154,155,156$ \\
& Patients with aromatase-inhibitor resistant breast cancer who respond to \\
Chloroquine & fulvestrant have markedly decreased IDO activity. IDO activity & correlates directly with number of metastases \\
Acyclovir & Also blocks PD1 & $157,158,159$ \\
\hline
\end{tabular}

COX2: Cyclo-oxygenase2; PD1: programmed cell death protein 1; TDO: tryptophan 2,3-dioxygenase.

Table II. Important natural products with anti-indoleamine 2,3-dioxygenase (IDO) activity.

\begin{tabular}{lcc}
\hline Natural product & Comment & Reference \\
\hline Curcumin & Also an inhibitor of PDL1, PDL2 and CTLA4. Synergistic & $143,162,163,164$, \\
& with PD1 and CTLA4 inhibitors. Protects against & $167,168,169$, \\
& quinolinic acid stimulation of NMDA receptors. & $170,171,172$ \\
Resveratrol & Also inhibits PD1, PDL1 and CTLA4. & $172,173,174,175,176$ \\
Epigallocatechin-3-gallate & Major catechin in green tea. Activity comparable to & $177,178,179$, \\
& 1-methyltryptophan in IDO suppression and in prevention of & $180,181,182$ \\
Rosmarinic acid (rosemary extract) & azoxymethane-induced colon carcinogenesis. & 183 \\
Genistein & Caffeic acid ester found in herbs such as basil, thyme and sage & 184,185 \\
Quercetin & Isoflavone prominent in soy products. May have estrogenic effects & $162,185,186$ \\
Brassinin & Found in green tea, onions, red wine. Also in ginkgo biloba, St. John's wort & $187,188,189,190$ \\
Apigenin (4,5,7-trihydroxyflavone) & Phytoalexin, indole mimetic, found in cabbage, & 185,191 \\
& broccoli, cauliflower and other foods. & 190 \\
\hline
\end{tabular}

PD1: Programmed cell death protein 1; PD2: programmed cell death protein 2; PDL1: programmed death-ligand 1; CTLA4: cytotoxic T-lymphocyteassociated protein- 4 .

\section{Conflicts of Interest}

Dr. Peter Sordillo is a member of the Scientific Advisory Board of SignPath Pharma, a developmental stage biotechnology company that is studying liposomal curcumin, liposomes and other agents. Dr. Helson is CEO of SignPath Pharma. Laura Sordillo reports no conflicts.

\section{References}

1 National Brain Tumor Society. http://braintumor.org/braintumor-information/understanding-brain-tumors/tumor-types/

2 Ostrom QT, Bauchet L, Davis FG, Deltour I, Fisher JL, Langer CE, Pekmezci M, Schwartzbaum JA, Turner MC, Walsh KM and Wrensch MR: The epidemiology of glioma in adults: a "state of the science" review. Neuro Oncol 16(7): 896-913, 2014.
3 Schoemaker MJ, Swerdlow AJ, Hepworth SJ, McKinney PA, Van Tongeren M and Muir KR: History of allergies and risk of glioma in adults. Int J Cancer 119(9): 2165-2172, 2006.

4 Wiemels JL, Wilson D, Patil C, Patoka J, McCoy L, Rice T, Schwartzbaum J, Heimberger A, Sampson JH, Chang S, Prados $\mathrm{M}$, Wiencke JK and Wrensch M: IgE, allergy, and risk of glioma: update from the San Francisco Bay area adult glioma study in the temozolomide era. Int J Cancer 125(3): 680-687, 2009.

5 Nduom EK, Weller M and Heimberger AB: Immunosuppressive mechanisms in glioblastoma. Neuro Oncol 17(Suppl 7): vii9vii14, 2015.

6 Gustafson MP, Lin Y, New KC, Bulur PA, O'neill BP, Gastineau DA and Dietz AB: Systemic immune suppression in glioblastoma: the interplay between CD14+ HLA-DRlo/neg monocytes, tumor factors, and dexamethasone. Neuro Oncol 12(7): 631-644, 2010. 
7 Waziri A: Glioblastoma-derived mechanisms of systemic immunosuppression. Neurosurg Clin N Am 21(1): 31-42, 2010.

8 Vega EA, Graner MW and Sampson JH: Combating immunosuppression in glioma. Future Oncol 4(3): 433-442, 2008.

9 Moertel C, Xi J and Olin MR: Understanding and overcoming the immunosuppressive effects of glioma-induced immunosuppression. J Immunother Cancer 1(Suppl 1): P169, 2013.

10 Dimov I, Tasić D, Stefanović I and Dimov D: New insights into molecular basis of glioblastoma multiforme and associated immunosuppression. Acta Facultatis Medicae Naissensis 30(4): 165-184, 2013

11 Stupp R, Mason WP, van den Bent MJ, Weller M, Fisher B, Taphoorn MJ, Belanger K, Brandes AA, Marosi C, Bogdahn U, Curschmann J, Janzer RC, Ludwin SK, Gorlia T, Allgeier A, Lacombe D, Cairncross JG, Eisenhauer E and Mirimanoff RO: Radiotherapy plus concomitant and adjuvant temozolomide for glioblastoma. N Eng J Med 352(10): 987-996, 2005.

12 Darefsky AS, King JT Jr and Dubrow R: Adult glioblastoma multiforme survival in the temozolomide era: a populationbased analysis of surveillance, epidemiology, and end results registries. Cancer 118(8): 2163-2172, 2011.

13 Cohen MH, Johnson JR and Pazdur R: Food and drug administration drug approval summary: temozolomide plus radiation therapy for the treatment of newly diagnosed glioblastoma multiforme. Clin Cancer Res 11(19): 6767-6771, 2005.

14 Schabel FM Jr.: Nitrosoureas: a review of experimental antitumor activity. Cancer Treat Rep 60(6): 665-698, 1976.

15 Taal W, Oosterkamp H, Walenkamp AM, Dubbink HJ, Beerepoot LV, Hanse MC, Buter J, Honkoop AH, Boerman D, de Vos FY, Dinjens WN, Enting RH, Taphoorn MJ, van den Berkmortel FW, Jansen RL, Brandsma D, Bromberg JE, van Heuvel I, Vernhout RM, van der Holt B and van den Bent MJ: Single-agent bevacizumab or lomustine versus a combination of bevacizumab plus lomustine in patients with recurrent glioblastoma (BELOB trial): a randomised controlled phase II trial. Lancet Oncology 15(9): 943-953, 2014.

16 Lund EL, Spang-Thomsen M, Skovgaard-Poulsen H and Kristjansen PE: Tumor angiogenesis - a new therapeutic target in gliomas. Acta Neurol Scand 97(1): 52-62, 1998.

17 Sathornsumetee S, Reardon DA, Desjardins A, Quinn JA, Vredenburgh JJ and Rich JN: Molecularly targeted therapy for malignant glioma. Cancer 110(1): 13-24, 2007.

18 Mesti T, Ebert Moltara M, Boc M, Rebersek M and Ocvirk J: Bevacizumab and irinotecan in recurrent malignant glioma, a single institution experience. Radiol Oncol 49(1): 80-85, 2015.

19 Okonogi N, Shirai K, Oike T, Murata K, Noda SE, Suzuki Y and Nakano T: Topics in chemotherapy, molecular-targeted therapy, and immunotherapy for newly-diagnosed glioblastoma multiforme. Anticancer Res 35(3): 1229-1233, 2015.

20 Leroy $\mathrm{H}$, Vermandel M, Tétard M, Lejeune J, Mordon S and Reyns N: Interstitial photodynamic therapy and glioblastoma: light fractionation study on a preclinical model: preliminary results. e-mémoires de l'Académie Nationale de Chirurgie 15(1): 011-017, 2016

21 Wang L, Zhang Y, Wu X and Yu G: Aquaporins: new targets for cancer therapy. Technol Cancer Res Treat 15(6): 821-828, 2016.

22 Sordillo LA, Sordillo PP and Helson L: Sphingosine kinase inhibitors as maintenance therapy of glioblastoma after ceramide-induced response. Anticancer Res 36(5): 2085-2095, 2016.

23 Sordillo LA, Sordillo PP and Helson L: Curcumin for the treatment of glioblastoma. Anticancer Res 35(12): 6373-6378, 2015.

24 Yovino S and Grossman SA: Severity, etiology and possible consequences of treatment-related lymphopenia in patients with newly diagnosed high-grade gliomas. CNS Oncol 1(2): 149$154,2012$.

25 Authier A, Farrand KJ, Broadley KW, Ancelet LR, Hunn MK, Stone S, McConnell MJ and Hermans IF: Enhanced immunosuppression by therapy-exposed glioblastoma multiforme tumor cells. Int J Cancer 136(11): 2566-2578, 2015.

26 Slominski A, Semak I, Pisarchik A, Sweatman T, Szczesniewski A and Wortsman J: Conversion of L-tryptophan to serotonin and melatonin in human melanoma cells. FEBS Lett 511(1): 102-106, 2002.

27 Ikeda M, Tsuji H, Nakamura S, Ichiyama A, Nishizuka Y and Hayaishi O: Studies on the biosynthesis of nicotinamide adenine dinucleotide II. A role of picolinic carboxylase in the biosynthesis of nicotinamide adenine dinucleotide from tryptophan in mammals. J Biol Chem 240(3): 1395-1401, 1965.

28 Duleu S, Mangas A, Sevin F, Veyret B, Bessede A and Geffard M: Circulating antibodies to IDO/THO pathway metabolites in Alzheimer's disease. Int J Alzheimers Dis 501541: 1-6, 2010.

29 Iacono RP, Kuniyoshi SM, Ahlman JR, Zimmerman GJ, Maeda $\mathrm{G}$ and Pearlstein RD: Concentrations of indoleamine metabolic intermediates in the ventricular cerebrospinal fluid of advanced Parkinson's patients with severe postural instability and gait disorders. J Neural Transm 104(4-5): 451-459, 1997.

30 Mazarei G and Leavitt BR: Indoleamine 2,3-dioxygenase as a potential therapeutic target in Huntington's disease. J Huntington's Dis 4(2): 109-118, 2015.

31 Myint AM: Kynurenines: from the perspective of major psychiatric disorders. FEBS J 279(8): 1375-1385, 2012.

32 Mangge H, Stelzer I, Reininghaus EZ, Weghuber D, Postolache TT and Fuchs D: Disturbed tryptophan metabolism in cardiovascular disease. Curr Med Chem 21(17): 1931-1937, 2014.

33 Oxenkrug G: Insulin resistance and dysregulation of tryptophan-kynurenine and kynurenine-nicotinamide adenine dinucleotide metabolic pathways. Mol Neurobiol 48(2): 294301, 2013.

34 Guillemin GJ, Williams KR, Smith DG, Smythe GA, CroitoruLamoury $\mathrm{J}$ and Brew BJ: Quinolinic acid in the pathogenesis of Alzheimer's disease. In: Developments in Tryptophan and Serotonin Metabolism. Springer, New York, US, pp. 167-176, 2003.

35 Zinger A, Barcia C, Herrero MT and Guillemin GJ: The involvement of neuroinflammation and kynurenine pathway in Parkinson's disease. Parkinsons Dis 716859: 1-3, 2011.

36 Sanberg PR, Calderon SF, Giordano M, Tew JM and Norman AB: The quinolinic acid model of Huntington's disease: locomotor abnormalities. Exp Neurol 105(1): 45-53, 1989.

37 Guillemin GJ: Quinolinic acid, the inescapable neurotoxin. FEBS J 279(8): 1356-1365, 2012.

38 Lau A and Tymianski M: Glutamate receptors, neurotoxicity and neurodegeneration. Pflugers Arch 460(2): 525-542, 2010.

39 Atlante A, Calissano P, Bobba A, Giannattasio S, Marra E and Passarella S: Glutamate neurotoxicity, oxidative stress and mitochondria. FEBS Lett 497(1): 1-5, 2001. 
40 Choi DW, Maulucci-Gedde M and Kriegstein AR: Glutamate neurotoxicity in cortical cell culture. J Neurosci 7(2): 357-368, 1987.

41 Lugo-Huitrón R, Ugalde Muñiz P, Pineda B, Pedraza-Chaverrí J, Ríos C and Pérez-de la Cruz V: Quinolinic acid: an endogenous neurotoxin with multiple targets. Oxid Med Cell Longev 104024: 1-14, 2013.

42 Nemeth H, Toldi J and Vécsei L: Kynurenines, Parkinson's disease and other neurodegenerative disorders: preclinical and clinical studies. In: Parkinson's Disease and Related Disorders. Springer, Vienna pp. 285-304, 2006.

43 Olds ME, Jacques DB and Kopyov O: Behavioral and anatomical effects of quinolinic acid in the striatum of the hemiparkinsonian rat. Synapse 55(1): 26-36, 2005.

44 Ribeiro CA, Grando V, Dutra Filho CS, Wannmacher C and Wajner M: Evidence that quinolinic acid severely impairs energy metabolism through activation of NMDA receptors in striatum from developing rats. J Neurochem 99(6): 1531-1542, 2006.

45 Yen CL, Mar MH, Craciunescu CN, Edwards LJ and Zeisel SH: Deficiency in methionine, tryptophan, isoleucine, or choline induces apoptosis in cultured cells. J Nutr 132(7): 1840-1847, 2002.

46 Jrad-Lamine A, Henry-Berger J, Damon-Soubeyrand C, Saez F, Kocer A, Janny L, Pons-Rejraji H, Munn DH, Mellor AL, Gharbi $\mathrm{N}$ and Cadet R: Indoleamine 2,3-dioxygenase 1 (IDO1) is involved in the control of mouse caput epididymis immune environment. PLoS one 8(6): e66494, 2013.

47 Ino K, Yamamoto E, Shibata K, Kajiyama H, Yoshida N, Terauchi M, Nawa A, Nagasaka T, Takikawa O and Kikkawa F: Inverse correlation between tumoral indoleamine 2,3dioxygenase expression and tumor-infiltrating lymphocytes in endometrial cancer: its association with disease progression and survival. Anticancer Res 14(8): 2310-2317, 2008.

48 Suzuki Y, Suda T, Furuhashi K, Suzuki M, Fujie M, Hahimoto D, Nakamura Y, Inui N, Nakamura $\mathrm{H}$ and Chida $\mathrm{K}$ : Increased serum kynurenine/tryptophan ratio correlates with disease progression in lung cancer. Lung Cancer 67(3): 361-365, 2010.

49 Yoshida N, Ino K, Ishida Y, Kajiyama H, Yamamoto E, Shibata $\mathrm{K}$, Terauchi M, Nawa A, Akimoto H, Takikawa O, Isobe $\mathrm{K}$ and Kikkawa F: Overexpression of indoleamine 2,3-dioxygenase in human endometrial carcinoma cells induces rapid tumor growth in a mouse xenograft model. Clin Cancer Res 14(22): 72517259, 2008.

50 Chung KT and Gadupudi GS: Possible roles of excess tryptophan metabolites in cancer. Environ Mol Mutagen 52(2): 81-104, 2011.

51 Juhász C, Muzik O, Lu X, Jahania MS, Soubani AO, Khalaf M, Peng F, Mangner TJ, Chakraborty PK and Chugani DC: Quantification of tryptophan transport and metabolism in lung tumors using PET. J Nucl Med 50(3): 356-363, 2009.

52 Tankiewicz A, Dziemian'czyk D, Buczko P, Szarmach IJ, Grabowska SZ, and Pawlak D: Tryptophan and its metabolites in patients with oral squamous cell carcinoma: preliminary study. Adv Med Sci 51(1): 221-224, 2005.

53 Prendergast GC: Cancer: why tumours eat tryptophan. Nature 478(7368): 192-194, 2011.

54 Heng B, Lim CK, Lovejoy DB, Bessede A, Gluch L and Guillemin GJ: Understanding the role of the kynurenine pathway in human breast cancer immunobiology. Oncotarget 7(6): 6506, 2016.
55 Opitz CA, Litzenburger UM, Sahm F, Ott M, Tritschler I, Trump S, Schumacher T, Jestaedt L, Schrenk D, Weller M and Jugold M: An endogenous tumour-promoting ligand of the human aryl hydrocarbon receptor. Nature 478(7368): 197-203, 2011.

56 Sordillo LA, Pu Y, Sordillo PP, Budansky Y and Alfano RR: Optical spectral fingerprints of tissues from patients with different breast cancer histologies using a novel fluorescence spectroscopic device. Technol Cancer Res Treat 12(5): 455-461, 2013.

57 Banerjee B, Renkoski T, Graves LR, Rial NS, Tsikitis VL, Nfonsam V, Pugh J, Tiwari P, Gavini $\mathrm{H}$ and Utzinger U: Tryptophan autofluorescence imaging of neoplasms of the human colon. J Biomed Opt 17(1): 0160031-0160037, 2012.

$58 \mathrm{Pu} \mathrm{Y}$, Wang W, Yang Y and Alfano RR: Stokes shift spectroscopy highlights differences of cancerous and normal human tissues. Opt Lett 37(16): 3360-3362, 2012.

59 Brancaleon L, Durkin AJ, Tu JH, Menaker G, Fallon JD and Kollias N: In vivo fluorescence spectroscopy of nonmelanoma skin cancer. Photochem Photobiol 73(2): 178-183, 2001.

60 Sordillo LA, Sordillo PP, Budansky Y, Pu Y and Alfano RR: Differences in fluorescence profiles from breast cancer tissues due to changes in relative tryptophan content via energy transfer: tryptophan content correlates with histologic grade and tumor size but not with lymph node metastases. J Biomed Opt 19(12): 125002, 2014.

61 Pu Y, Xue J, Wang W, Xu B, Gu Y, Tang R, Ackerstaff E, Koutcher JA, Achilefu S and Alfano RR: Native fluorescence spectroscopy reveals spectral differences among prostate cancer cell lines with different risk levels. J Biomed Opt 18(8): 087002, 2013.

62 Zhou Y, Liu CH, Zhou L, Zhu K, Liu Y, Zhang L, BoydstonWhite S, Cheng G, Pu Y, Bidyut D and Alfano RR: Resonant Raman spectra of grades of human brain glioma tumors reveal the content of tryptophan by the $1588 \mathrm{~cm}-1$ mode. SPIE BiOS 931810: 931810-931810, 2015.

63 Yorucu C, Lau K, Mittar S, Green NH, Raza A, Rehman IU and MacNeil S: Raman spectroscopy detects melanoma and the tissue surrounding melanoma using tissue-engineered melanoma models. Appl Spectrosc Rev 51(4): 263-277, 2016.

64 Perry RT, Collins JS, Wiener H, Acton R, and Go RCP: The role of TNF and its receptors in Alzheimer's disease. Neurobiol Aging 22(6): 873-883, 2001.

65 Dufek M, Rektorova I, Thon V, Lokaj J, and Rektor I: Interleukin-6 may contribute to mortality in Parkinson's disease patients: A 4-year prospective study. Parkinson's Disease 898192: 1-5, 2015.

66 Hsiao H, Chiu F, Chen C, Wu Y, Chen H, Chen Y, Kuo H, and Chern Y: Inhibition of soluble tumor necrosis factor is therapeutic in Huntington's disease. Hum Mol Genet 23(16): 4328-4344, 2014.

67 Hirsch EC and Hunot S: Neuroinflammation in Parkinson's disease: a target for neuroprotection. Lancet Neurol 8(4): 382397, 2009.

68 Sordillo PP, Sordillo LA and Helson L: Bifunctional role of pro-inflammatory cytokines after traumatic brain injury. Brain Inj 30(9): 1043-1053, 2016.

69 Yan EB, Frugier T, Lim CK, Heng B, Sundaram G, Tan M, Rosenfeld JV, Walker DW, Guillemin GJ and MorgantiKossmann MC: Activation of the kynurenine pathway and 
increased production of the excitotoxin quinolinic acid following traumatic brain injury in humans. J Neuroinflammation 12(1): 110, 2015.

70 Bai L, Mao GP and Cao CP: Effects of inflammatory cytokines on the recurrence of liver cancer after an apparently curative operation. J Dig Dis 8(3): 154-159, 2007.

71 Grivennikov SI and Karin M: Inflammatory cytokines in cancer: tumour necrosis factor and interleukin 6 take the stage. Ann Rheum Dis 70(Suppl 1): i104-i108, 2011.

72 Esquivel-Velázquez M, Ostoa-Saloma P, Palacios-Arreola MI, Nava-Castro KE, Castro JI and Morales-Montor J: The role of cytokines in breast cancer development and progression. J Interferon Cytokine Res 35(1): 1-6, 2015.

73 Wajant H: The role of TNF in cancer. The role of TNF in cancer. In: Death Receptors and Cognate Ligands in Cancer. Kalthoff, Holger (ed.). Springer-Verlag, Berlin, pp. 1-15, 2009.

74 Yeung YT, McDonald KL, Grewal T and Munoz L: Interleukins in glioblastoma pathophysiology: implications for therapy. $\mathrm{Br}$ J Pharmacol 168(3): 591-606, 2013.

75 Wolpert F, Happold C, Reifenberger G, Florea AM, Deenen R, Roth P, Neidert MC, Lamszus K, Westphal M, Weller M and Eisele $\mathrm{G}$ : Interferon- $\beta$ modulates the innate immune response against glioblastoma initiating cells. Plos One 10(10): e0139603, 2015.

76 Piperi C, Zisakis A, Lea RW and Kalofoutis A: Role of cytokines in the regulation of glioma tumor growth and angiogenesis. Am J Immunol 1(3): 104-112, 2005.

77 Campbell BM, Charych E, Lee AW and Möller T: Kynurenines in CNS disease: regulation by inflammatory cytokines. Front Neurosci 8(12): 1-12, 2014.

78 Asp L, Johansson AS, Mann A, Owe-Larsson B, Urbanska EM, Kocki T, Kegel M, Engberg G, Lundkvist GB and Karlsson H: Effects of pro-inflammatory cytokines on expression of kynurenine pathway enzymes in human dermal fibroblasts. J Inflamm 8(25): 1-7, 2011.

79 Zuo H, Ueland PM, Ulvik A, Eussen SJ, Vollset SE, Nygård O, Midttun $\varnothing$, Theofylaktopoulou D, Meyer K and Tell GS: Plasma biomarkers of inflammation, the kynurenine pathway, and risks of all-cause, cancer, and cardiovascular disease mortality: The Hordaland Health Study. Am J Epidemiol 183(4): 249-258, 2016.

80 Paguirigan AM, Byrne GI, Becht S and Carlin JM: Cytokinemediated indoleamine 2,3-dioxygenase induction in response to Chlamydia infection in human macrophage cultures. Infection and immunity 62(4): 1131-1136, 1994.

81 Stepulak A, Rola R, Polberg K and Ikonomidou C: Glutamate and its receptors in cancer. J Neural Transm 121(8): 933-944, 2014.

82 Luksch H, Uckermann O, Stepulak A, Hendruschk S, Marzahn J, Bastian S, Staufner C, Temme A and Ikonomidou C: Silencing of selected glutamate receptor subunits modulates cancer growth. Anticancer Res 31(10): 3181-3192, 2011.

83 Willard SS and Koochekpour S: Glutamate signaling in benign and malignant disorders: current status, future perspectives, and therapeutic implications. Int J Biol Sci 9(7): 728-742, 2013.

84 Sordillo PP, Reiman RE, Benua RS, Gelbard AS, Magill GB, Rosen G and Laughlin JS: Quantitative scanning of soft-tissue sarcomas with nitrogen-13-labeled L-glutamate. Cancer Invest 1(5): 387-393, 1983.

85 Fallarino F, Grohmann U, Vacca C, Bianchi R, Orabona C, Spreca A, Fioretti MC and Puccetti P: T cell apoptosis by tryptophan catabolism. Cell Death Differ 9(10): 1069, 2002.

86 Mbongue JC, Nicholas DA, Torrez TW, Kim NS, Firek AF and Langridge WH: The role of indoleamine 2,3-dioxygenase in immune suppression and autoimmunity. Vaccines 3(3): 703$729,2015$.

87 Frumento G, Rotondo R, Tonetti M, Damonte G, Benatti U and Ferrara GB: Tryptophan-derived catabolites are responsible for inhibition of T- and natural-killer cell proliferation induced by indoleamine 2,3-dioxygenase. J Exp Med 196(4): 459-468, 2002.

88 Terness P, Bauer TM, Röse L, Dufter C, Watzlik A, Simon H and Opelz G: Inhibition of allogeneic T-cell proliferation by indoleamine 2, 3-dioxygenase-expressing dendritic cells. J Exp Med 196(4): 447-457, 2002.

89 Meisel R, Zibert A, Laryea M, Göbel U, Däubener W and Dilloo D: Human bone marrow stromal cells inhibit allogeneic T-cell responses by indoleamine 2, 3-dioxygenase-mediated tryptophan degradation. Blood 103(12): 4619-4621, 2004.

90 Jürgens B, Hainz U, Fuchs D, Felzmann T and Heitger A: Interferon- $\gamma$-triggered indoleamine 2, 3-dioxygenase competence in human monocyte-derived dendritic cells induces regulatory activity in allogeneic T-cells. Blood 114(15): 32353243, 2009.

91 Albulescu R, Codrici E, Popescu ID, Mihai S, Necula LG, Petrescu D, Teodoru M and Tanase CP: Cytokine patterns in brain tumour progression. Mediators Inflamm 979748: 1-7, 2013.

92 Zhu VF, Yang J, LeBrun DG and Li M: Understanding the role of cytokines in glioblastoma multiforme pathogenesis. Cancer Lett 316(2): 139-150, 2012.

93 El Jamal SM, Taylor EB, Elmageed ZY, Alamodi AA, Selimovic D, Alkhateeb A, Hannig M, Hassan SY, Santourlidis S, Friedlander PL and Haikel Y: Interferon gamma-induced apoptosis of head and neck squamous cell carcinoma is connected to indoleamine 2, 3-dioxygenase via mitochondrial and ER stress-associated pathways. Cell Div 11(1): 11, 2016.

94 Sarkar SA, Wong R, Hackl SI, Moua O, Gill RG, Wiseman A, Davidson HW and Hutton JC: Induction of indoleamine 2, 3dioxygenase by interferon- $\gamma$ in human islets. Diabetes $56(1)$ : 72-79, 2007.

95 Godin-Ethier J, Hanafi LA, Piccirillo CA and Lapointe R: Indoleamine 2, 3-dioxygenase expression in human cancers: clinical and immunologic perspectives. Clin Cancer Res 17(22): 6985-6991, 2011.

96 Ball HJ, Sanchez-Perez A, Weiser S, Austin CJ, Astelbauer F, Miu J, McQuillan JA, Stocker R, Jermiin LS and Hunt NH: Characterization of an indoleamine 2, 3-dioxygenase-like protein found in humans and mice. Gene 396(1): 203-213, 2007.

97 Ball HJ, Yuasa HJ, Austin CJ, Weiser S and Hunt NH: Indoleamine 2,3-dioxygenase-2; a new enzyme in the kynurenine pathway. Int J Biochem Cell Biol 41(3): 467-471, 2009.

98 Fatokun AA, Hunt $\mathrm{NH}$ and Ball HJ: Indoleamine 2, 3dioxygenase 2 (IDO2) and the kynurenine pathway: characteristics and potential roles in health and disease. Amino Acids 45(6): 1319-1329, 2013.

99 Curti A, Trabanelli S, Salvestrini V, Baccarani M and Lemoli RM: The role of indoleamine 2,3-dioxygenase in the induction of immune tolerance: focus on hematology. Blood 113(11): 2394-2401, 2009. 
100 Munn DH, Zhou M, Attwood JT, Bondarev I, Conway SJ, Marshall B, Brown C and Mellor AL: Prevention of allogeneic fetal rejection by tryptophan catabolism. Science 281(5380): 1191-1193, 1998.

101 Schröcksnadel K, Wirleitner B, Winkler C and Fuchs D: Monitoring tryptophan metabolism in chronic immune activation. Clin Chim Acta 364(1): 82-90, 2006.

102 Hainz U, Jurgens B, Wekerle T, Seidel MG and Heitger A: Indoleamine 2,3-dioxygenase in hematopoietic stem cell transplantation. Curr Drug Metab 8(3): 267-272, 2007.

103 Jasperson LK, Bucher C, Panoskaltsis-Mortari A, Taylor PA, Mellor AL, Munn DH and Blazar BR: Indoleamine 2,3dioxygenase is a critical regulator of acute graft-versus-host disease lethality. Blood 111(6): 3257-3265, 2008.

104 Moon YW, Hajjar J, Hwu P and Naing A: Targeting the indoleamine 2,3-dioxygenase pathway in cancer. J Immunother Cancer 3(1): 51, 2015.

105 Mellor AL and Munn DH: IDO expression by dendritic cells: tolerance and tryptophan catabolism. Nat Rev Immunol 4(10): 762-774, 2004.

106 Théate I, van Baren N, Pilotte L, Moulin P, Larrieu P, Renauld JC, Hervé C, Gutierrez-Roelens I, Marbaix E, Sempoux C and Van den Eynde BJ: Extensive profiling of the expression of the indoleamine 2,3-dioxygenase 1 protein in normal and tumoral human tissues. Cancer Immunol Res 3(2): 161-172, 2015.

107 Munn DH and Mellor AL: Indoleamine 2,3-dioxygenase and metabolic control of immune responses. Trends Immunol 34(3): 137-143, 2013

108 Heitger A: Regulation of expression and function of IDO in human dendritic cells. Curr Med Chem 18(15): 2222-2233, 2011.

109 Johnson TS and Munn DH: Host indoleamine 2,3-dioxygenase: contribution to systemic acquired tumor tolerance. Immunol Invest 41(6-7): 765-797, 2012.

110 Schmidt SK, Müller A, Heseler K, Woite C, Spekker K, MacKenzie CR and Däubener W: Antimicrobial and immunoregulatory properties of human tryptophan 2,3dioxygenase. Eur J Immunol 39(10): 2755-2764, 2009.

111 Wu W, Nicolazzo JA, Wen L, Chung R, Stankovic R, Bao SS, Lim CK, Brew BJ, Cullen KM and Guillemin GJ: Expression of tryptophan 2,3-dioxygenase and production of kynurenine pathway metabolites in triple transgenic mice and human Alzheimer's disease brain. PloS One 8(4): e59749, 2013.

112 Soichot M, Vaast A, Vignau J, Guillemin GJ, Lhermitte M, Broly $\mathrm{F}$ and Allorge D: Characterization of functional polymorphisms and glucocorticoid-responsive elements in the promoter of TDO2, a candidate gene for ethanol-induced behavioural disorders. Alcohol Alcohol 48(4): 415-425, 2013.

113 Breda C, Sathyasaikumar KV, Idrissi SS, Notarangelo FM, Estranero JG, Moore GG, Green EW, Kyriacou CP, Schwarcz $\mathrm{R}$ and Giorgini F: Tryptophan-2,3-dioxygenase (TDO) inhibition ameliorates neurodegeneration by modulation of kynurenine pathway metabolites. Proc Natl Acad Sci 113(19): 5435-5440, 2016.

114 Nabi R, Serajee FJ, Chugani DC, Zhong H and Huq AH: Association of tryptophan 2,3 dioxygenase gene polymorphism with autism. Am J Med Genet B Neuropsychiatr Genet 125(1): 63-68, 2004.

115 Mautino MR, Metz RA, Jaipuri F, Waldo J, Kumar S, Marcinowicz-Flick A, Potturi H, Adams JT, Van Allen C,
Vahanian NN and Link CJ: Novel specific-and dual-tryptophan2,3-dioxygenase (TDO) and indoleamine-2,3-dioxygenase (IDO) inhibitors for tumor immunotherapy. Cancer Res 74(19): 1633,2014

116 Pilotte L, Larrieu P, Stroobant V, Colau D, Dolušić E, Frédérick R, De Plaen E, Uyttenhove C, Wouters J, Masereel B and Van den Eynde BJ: Reversal of tumoral immune resistance by inhibition of tryptophan 2,3-dioxygenase. Proc Natl Acad Sci 109(7): 2497-2502, 2012.

117 Puccetti P, Fallarino F, Italiano A, Soubeyran I, MacGrogan G, Debled M, Velasco V, Bodet D, Eimer S, Veldhoen M and Prendergast GC: Accumulation of an endogenous tryptophanderived metabolite in colorectal and breast cancers. PloS One 10(4): e0122046, 2015

118 D'Amato NC, Rogers TJ, Gordon MA, Greene LI, Cochrane DR, Spoelstra NS, Nemkov TG, D'Alessandro A, Hansen KC and Richer JK: A TDO2-AhR signaling axis facilitates anoikis resistance and metastasis in triple-negative breast cancer. Cancer Res 75(21): 4651-4664, 2015.

119 Kmiecik J, Poli A, Brons NH, Waha A, Eide GE, Enger PØ, Zimmer $\mathrm{J}$ and Chekenya M: Elevated $\mathrm{CD}^{+}$and $\mathrm{CD}^{+}$tumorinfiltrating immune cells correlate with prolonged survival in glioblastoma patients despite integrated immunosuppressive mechanisms in the tumor microenvironment and at the systemic level. J Neuroimmunol 264(1): 71-83, 2013.

120 Grossauer S, Koeck K and Petritsch C: Immune checkpoint blockage - a promising strategy to overcome glioma stem cell therapy resistance. Insights Neurosurg 1(1): 1-8, 2016.

121 Avril T, Saikali S, Vauléon E, Jary A, Hamlat A, De Tayrac M, Mosser $\mathrm{J}$ and Quillien V: Distinct effects of human glioblastoma immunoregulatory molecules programmed cell death ligand-1 (PDL1) and indoleamine 2,3-dioxygenase (IDO) on tumour-specific T-cell functions. J Neuroimmunol 225(1): 22-33, 2010

122 Anderson AC: TIM-3: an emerging target in the cancer immunotherapy landscape. Cancer Immunol Res 2(5): 393-398, 2014.

123 Woo SR, Turnis ME, Goldberg MV, Bankoti J, Selby M, Nirschl CJ, Bettini ML, Gravano DM, Vogel P, Liu CL and Tangsombatvisit S: Immune inhibitory molecules LAG-3 and PD1 synergistically regulate T-cell function to promote tumoral immune escape. Cancer Res 72(4): 917-927, 2012.

124 Benson DM, Cohen AD, Jagannath S, Munshi NC, Spitzer G, Hofmeister CC, Efebera YA, Andre P, Zerbib R and Caligiuri MA: A phase I trial of the anti-KIR antibody IPH2101 and lenalidomide in patients with relapsed/refractory multiple myeloma. Clin Cancer Res 21(18): 4055-4061, 2015.

125 Lines JL, Pantazi E, Mak J, Sempere LF, Wang L, O'Connell S, Ceeraz S, Suriawinata AA, Yan S, Ernstoff MS and Noelle R: VISTA is an immune checkpoint molecule for human Tcells. Cancer Res 74(7): 1924-1932, 2014.

126 Fellner C: Ipilimumab (yervoy) prolongs survival in advanced melanoma: serious side effects and a hefty price tag may limit its use. Pharm Therapeutics 37(9): 503, 2012.

127 Tomasini P, Khobta N, Greillier L and Barlesi F: Ipilimumab: its potential in non-small cell lung cancer. Ther Adv Med Oncol 4(2): 43-50, 2012.

128 Sundar R, Cho BC, Brahmer JR and Soo RA: Nivolumab in NSCLC: latest evidence and clinical potential. Ther Adv Med Oncol 7(2): 85-96, 2015. 
129 Fuereder T: Immunotherapy for head and neck squamous cell carcinoma. Memo 9(2): 66-69, 2016.

130 Redman JM, Gibney GT and Atkins MB: Advances in immunotherapy for melanoma. BMC Med 14(1): 20, 2016.

131 Powles T, Eder JP, Fine GD, Braiteh FS, Loriot Y, Cruz C, Bellmunt J, Burris HA, Petrylak DP, Teng SL and Shen X: MPDL3280A (anti-PD-L1) treatment leads to clinical activity in metastatic bladder cancer. Nature 515(7528): 558-562, 2014.

$132 \mathrm{Kim}$ J: Immune checkpoint blockade therapy for bladder cancer treatment. Investig Clin Urol 57(Suppl 1): S98-S105, 2016.

133 Reardon DA, Gokhale PC, Klein SR, Ligon KL, Rodig SJ, Ramkissoon SH, Jones KL, Conway AS, Liao X, Zhou J and Wen PY: Glioblastoma eradication following immune checkpoint blockade in an orthotopic, immunocompetent model. Cancer Immunol Res 4(2): 124-135, 2016.

134 Lim M, Weller M and Chiocca EA: Current state of immunebased therapies for glioblastoma. Am Soc Clin Oncol Educ Book 35: e132-139, 2016.

135 Schaff LR, Lassman AB, Goldlust SA, Cloughesy T, Singer S, Schwartz GK and Iwamoto FM: ET-53 ipilinumab for recurrent glioblastoma (GBM). Neuro Oncol 16(5): v90, 2014.

136 Donovan L, Schaff L, Lassman A, Wang T, Carvajal R, Rizvi N, Fox A and Iwamoto F: PD1 inhibitors for recurrent highgrade glioma (HGG). Neurology 86(16 Suppl): P6-294, 2016.

137 Zeng J, See AP, Phallen J, Jackson CM, Belcaid Z, Ruzevick J, Durham N, Meyer C, Harris TJ, Albesiano E and Pradilla G: Anti-PD1 blockade and stereotactic radiation produce long-term survival in mice with intracranial gliomas. Int $\mathrm{J}$ Radiat Oncol Biol Phys 86(2): 343-349, 2013

138 Antonios JP, Soto H, Everson RG, Orpilla J, Moughon D, Shin N, Sedighim S, Yong WH, Li G, Cloughesy TF and Liau LM: PD1 blockade enhances the vaccination-induced immune response in glioma. JCI Insight 1(10): e87059, 2016.

139 Carter T, Shaw H, Cohn-Brown D, Chester K and Mulholland $\mathrm{P}$ : Ipilimumab and bevacizumab in glioblastoma. Clin Oncol 28(10): 622-626, 2016.

140 Chen Y and Guillemin GJ: Kynurenine pathway metabolites in humans: disease and healthy states. Int J Tryptophan Res 2: 119, 2009.

141 Röhrig UF, Majjigapu SR, Vogel P, Zoete V and Michielin O: Challenges in the discovery of indoleamine 2,3-dioxygenase 1 (IDO1) inhibitors. J Med Chem 58(24): 9421-9437, 2015.

142 Schroecksnadel K, Winkler C, Wirleitner B, Schennach H and Fuchs D: Aspirin down-regulates tryptophan degradation in stimulated human peripheral blood mononuclear cells in vitro. Clin Exp Immunol 140(1): 41-45, 2005.

143 Chen S, Corteling R, Stevanato L and Sinden J: Natural inhibitors of indoleamine 3,5-dioxygenase induced by interferon-gamma in human neural stem cells. Biochem Biophys Res Commun 429(1): 117-123, 2012.

144 Sayama S, Yoshida R, Oku T, Imanishi J, Kishida T and Hayaishi O: Inhibition of interferon-mediated induction of indoleamine 2,3-dioxygenase in mouse lung by inhibitors of prostaglandin biosynthesis. Proc Natl Acad Sci 78(12): $7327-$ 7330, 1981.

145 Zhou L, Chen H, Wen Q and Zhang Y: Indoleamine 2,3dioxygenase expression in human inflammatory bowel disease. Eur J Gastroenterol Hepatol 24(6): 695-701, 2012.

146 Lee SY, Choi HK, Lee KJ, Jung JY, Hur GY, Jung KH, Kim JH, Shin C, Shim JJ, In KH and Kang KH: The immune tolerance of cancer is mediated by IDO that is inhibited by COX2 inhibitors through regulatory T-cells. J Immunother 32(1): 22-28, 2009.

147 Basu GD, Tinder TL, Bradley JM, Tu T, Hattrup CL, Pockaj BA and Mukherjee P: Cyclooxygenase-2 inhibitor enhances the efficacy of a breast cancer vaccine: role of IDO. J Immunol 177(4): 2391-2402, 2006.

148 Lee SY, Lee KJ, Jung JY, Lee EJ, Kang EH, Jung KH, Lee SY, Kim JH, Shin $\mathrm{C}$ and Shim JJ: In KH. Cyclooxygenase-2 (COX2) inhibitors reduce immune tolerance through indoleamine 2,3-dioxygenase (IDO). Lung Cancer 6(1): 15-23, 2007.

149 Cesario A, Rocca B and Rutella S: The interplay between indoleamine 2,3-dioxygenase 1 (IDO1) and cyclooxygenase (COX)-2 in chronic inflammation and cancer. Curr Med Chem 18(15): 2263-2271, 2011.

150 Iachininoto MG, Nuzzolo ER, Bonanno G, Mariotti A, Procoli A, Locatelli F, Cristofaro RD and Rutella S: Cyclooxygenase2 (COX2) inhibition constrains indoleamine 2,3-dioxygenase 1 (IDO1) activity in acute myeloid leukaemia cells. Molecules 18(9): 10132-10145, 2013.

151 Maneechotesuwan K, Ekjiratrakul W, Kasetsinsombat K, Wongkajornsilp A and Barnes PJ: Statins enhance the antiinflammatory effects of inhaled corticosteroids in asthmatic patients through increased induction of indoleamine 2,3dioxygenase. J Allergy Clin Immunol 126(4): 754-762, 2010.

152 Azor MH, Dos Santos JC, Futata EA, de Brito CA, Maruta CW, Rivitti EA, da Silva Duarte AJ and Sato MN: Statin effects on regulatory and proinflammatory factors in chronic idiopathic urticaria. Clin Exp Immunol 166(2): 291-298, 2011.

153 Wirleitner B, Sperner-Unterweger B and Fuchs D: Statins to reduce risk of depression. J Am Coll Cardiol 43(6): 1132, 2004.

154 Sakurai K, Fujisaki S, Suzuki S, Adachi K, Nagashima S, Masuo Y, Tomita R, Gonda K, Enomoto K, Amano S and Matsuo S: Indoleamine 2,3-dioxygenase activity during fulvestrant therapy for aromatase inhibitor-resistant metastatic breast cancer. Gan To Kagaku Ryoho 42(10): 1225-1227, 2015.

155 Xiao BG, Liu X and Link H: Antigen-specific T-cell functions are suppressed over the estrogen-dendritic cell-indoleamine 2,3dioxygenase axis. Steroids 69(10): 653-659, 2004.

$156 \mathrm{Lu} \mathrm{J}, \mathrm{Xu} \mathrm{Y,} \mathrm{Hu} \mathrm{W,} \mathrm{Gao} \mathrm{Y,} \mathrm{Ni} \mathrm{X,} \mathrm{Sheng} \mathrm{H} \mathrm{and} \mathrm{Liu} \mathrm{Y:} \mathrm{Exercise}$ ameliorates depression-like behavior and increases hippocampal BDNF level in ovariectomized rats. Neurosci Lett 573: 13-18, 2014.

157 Gostner JM, Schröcksnadel S, Becker K, Jenny M, Schennach $\mathrm{H}$, Überall $\mathrm{F}$ and Fuchs $\mathrm{D}$ : Antimalarial drug chloroquine counteracts activation of indoleamine $(2,3)$-dioxygenase activity in human PBMC. FEBS Open Bio 2(1): 241-245, 2012.

158 Martinson JA, Montoya CJ, Usuga X, Ronquillo R, Landay AL and Desai SN: Chloroquine modulates HIV-1-induced plasmacytoid dendritic cell alpha interferon: implication for Tcell activation. Antimicrobial agents and chemotherapy 54(2): 871-881, 2010.

159 Eldredge HB, DeNittis A, DuHadaway JB, Chernick M, Metz $\mathrm{R}$ and Prendergast GC: Concurrent whole brain radiotherapy and short-course chloroquine in patients with brain metastases: a pilot trial. J Radiat Oncol 2(3): 315-321, 2013.

160 Söderlund J, Erhardt S and Kast RE: Acyclovir inhibition of IDO to decrease Tregs as a glioblastoma treatment adjunct. J Neuroinflammation 7(1): 44, 2010. 
161 Müller AC and Daya S: Acyclovir inhibits rat liver tryptophan2,3-dioxygenase and induces a concomitant rise in brain serotonin and 5-hydroxyindole acetic acid levels. Metab Brain Dis 23(3): 351-360, 2008.

162 Yamamoto R, Yamamoto Y, Imai S, Fukutomi R, Ozawa Y, Abe M, Matuo Y and Saito K: Effects of various phytochemicals on indoleamine 2,3-dioxygenase 1 activity: galanal is a novel, competitive inhibitor of the enzyme. PLoS One 9(2): e88789, 2014.

163 Chang YF, Chuang HY, Hsu CH, Liu RS, Gambhir SS and Hwang JJ: Immunomodulation of curcumin on adoptive therapy with $\mathrm{T}$ cell functional imaging in mice. Cancer Prev Res 5: 444452, 2012.

164 Jeong YI, Kim SW, Jung ID, Lee JS, Chang JH, Lee CM, Chun SH, Yoon MS, Kim GT, Ryu SW and Kim JS: Curcumin suppresses the induction of indoleamine 2,3-dioxygenase by blocking the Janus-activated kinase-protein kinase C $\delta$-STAT 1 signaling pathway in interferon- $\gamma$-stimulated murine dendritic cells. J Biol Chem 284(6): 3700-3708, 2009.

165 Jiang GM, Xie WY, Wang HS, Du J, Wu BP, Xu W, Liu HF, Xiao P, Liu ZG, Li HY and Liu SQ: Curcumin combined with FAP $\alpha c$ vaccine elicits effective antitumor response by targeting indolamine-2,3-dioxygenase and inhibiting EMT induced by TNF- $\alpha$ in melanoma. Oncotarget 6(28): 25932, 2015.

166 Rogers NM, Kireta S and Coates PT: Curcumin induces maturation-arrested dendritic cells that expand regulatory T-cells in vitro and in vivo. Clin Exp Immunol 162(3): 460-473, 2010.

167 Hayakawa T, Sugiyama J, Yaguchi T, Imaizumi A and Kawakami Y: Enhanced anti-tumor effects of the PD1/PDL1 blockade by combining a highly absorptive form of NFkB/STAT3 inhibitor curcumin. J Immunother Cancer 2(3): P210, 2014.

168 Lim SO, Li CW, Xia W, Cha JH, Chan LC, Wu Y, Chang SS, Lin WC, Hsu JM, Hsu YH and Kim T: Deubiquitination and stabilization of PDL1 by CSN5. Cancer Cell 30(6): 925-939, 2016.

169 Zhao GJ, Lu ZQ, Tang LM, Wu ZS, Wang DW, Zheng JY and Qiu QM: Curcumin inhibits suppressive capacity of naturally occurring $\mathrm{CD} 4{ }^{+} \mathrm{CD} 25^{+}$regulatory T-cells in mice in vitro. Int Immunopharmacol 14(1): 99-106, 2012.

170 Bose S, Panda AK, Mukherjee S and Sa G: Curcumin and tumor immune-editing: resurrecting the immune system. Cell Div 10(1): 6, 2015.

171 Matteucci A, Cammarota R, Paradisi S, Varano M, Balduzzi M, Leo L, Bellenchi GC, De Nuccio C, Carnovale-Scalzo G, Scorcia $G$ and Frank C: Curcumin protects against NMDAinduced toxicity: a possible role for NR2A subunit. Invest Ophthalmol Vis Sci 52(2): 1070-1077, 2011.

172 Chiba T: STAT3 inhibitors for cancer therapy-the rationale and remained problems. EC Cancer 1: S1, 2016.

173 Noh KT, Chae SH, Chun SH, Jung ID, Kang HK and Park YM: Resveratrol suppresses tumor progression via the regulation of indoleamine 2,3-dioxygenase. Biochem Biophys Res Commun 431(2): 348-353, 2013.

174 Wirleitner B, Schroecksnadel K, Winkler C, Schennach H and Fuchs D: Resveratrol suppresses interferon- $\gamma$-induced biochemical pathways in human peripheral blood mononuclear cells in vitro. Immunol Lett 100(2): 159-163, 2005.

175 Opitz CA, Litzenburger UM, Lutz C, Lanz TV, Tritschler I, Köppel A, Tolosa E, Hoberg M, Anderl J, Aicher WK and Weller M: Toll-like receptor engagement enhances the immunosuppressive properties of human bone marrow-derived mesenchymal stem cells by inducing indoleamine-2,3dioxygenase- 1 via interferon- $\beta$ and protein kinase R. Stem cells 27(4): 909-919, 2009.

176 Li CW, Lim SO, Xia W, Lee HH, Chan LC, Kuo CW, Khoo KH, Chang SS, Cha JH, Kim T and Hsu JL: Glycosylation and stabilization of programmed death ligand-1 suppresses T-cell activity. Nat Commun 7: 12632, 2016.

177 Cheng CW, Shieh PC, Lin YC, Chen YJ, Lin YH, Kuo DH, Liu JY, Kao JY, Kao MC and Way TD: Indoleamine 2,3dioxygenase, an immunomodulatory protein, is suppressed by (-)-epigallocatechin-3-gallate via blocking of $\gamma$-interferoninduced JAK-PKC- $\delta$-STAT1 signaling in human oral cancer cells. J Agric Food Chem 58(2): 887-894, 2009.

178 Casey SC, Amedei A, Aquilano K, Azmi AS, Benencia F, Bhakta D, Bilsland AE, Boosani CS, Chen S, Ciriolo MR and Crawford S: Cancer prevention and therapy through the modulation of the tumor microenvironment. Semin Cancer Biol 35(Suppl): S199-S223, 2015.

179 Jeong YI, Jung ID, Lee JS, Lee CM, Lee JD and Park YM: (-)Epigallocatechin gallate suppresses indoleamine 2,3-dioxygenase expression in murine dendritic cells: Evidences for the COX-2 and STAT1 as potential targets. Biochem Biophys Res Commun 354(4): 1004-1009, 2007.

180 Ogawa K, Hara T, Shimizu M, Nagano J, Ohno T, Hoshi M, Ito H, Tsurumi H, Saito K, Seishima M and Moriwaki H: (-)Epigallocatechin gallate inhibits the expression of indoleamine 2,3-dioxygenase in human colorectal cancer cells. Oncol Lett 4(3): 546-550, 2012.

181 Ogawa K, Hara T, Shimizu M, Ninomiya S, Nagano J, Sakai $\mathrm{H}$, Hoshi M, Ito H, Tsurumi H, Saito K and Seishima M: Suppression of azoxymethane-induced colonic preneoplastic lesions in rats by 1-methyltryptophan, an inhibitor of indoleamine 2,3-dioxygenase. Cancer Sci 103(5): 951-958, 2012.

182 Shirakami Y, Sakai H, Kubota M, Kochi T and Shimizu M: Dietary phytochemicals as cancerpreventive agents: efficacy and mechanisms. J Bioanal Biomed 7(2): 40, 2015.

183 Lee HJ, Jeong YI, Lee TH, Jung ID, Lee JS, Lee CM, Kim JI, Joo H, Lee JD and Park YM: Rosmarinic acid inhibits indoleamine 2,3-dioxygenase expression in murine dendritic cells. Biochem Pharmacol 73(9): 1412-1421, 2007.

184 Koide $\mathrm{Y}$ and Yoshida A: The signal transduction mechanism responsible for gamma interferon-induced indoleamine 2,3dioxygenase gene expression. Infection and Immunity 62(3): 948-955, 1994.

185 Chen SS, Corteling R, Stevanato L and Sinden J: Polyphenols inhibit indoleamine 3, 5-dioxygenase-1 enzymatic activity - a role of immunomodulation in chemoprevention. Discov Med 14(78): 327-333, 2012.

186 Singh T, Kaur T and Goel RK: Adjuvant quercetin therapy for combined treatment of epilepsy and comorbid depression. Neurochem Int 104: 27-33, 2017.

187 Banerjee T, Duhadaway JB, Gaspari P, Sutanto-Ward E, Munn DH, Mellor AL, Malachowski WP, Prendergast GC and Muller AJ: A key in vivo antitumor mechanism of action of natural product-based brassinins is inhibition of indoleamine 2,3dioxygenase. Oncogene 27(20): 2851-2857, 2008.

188 Gaspari P, Banerjee T, Malachowski WP, Muller AJ, Prendergast GC, DuHadaway J, Bennett $\mathrm{S}$ and Donovan AM: 
Structure-activity study of brassinin derivatives as indoleamine 2,3-dioxygenase inhibitors. J Med Chem 49(2): 684-692, 2006.

189 Muller A, DuHadaway J, Banerjee T, Munn D, Mellor A, Gaspari P, Malachowski W and Prendergast G: Brassinin compounds exhibit anticancer activity mediated through inhibition of the immunotolerogenic enzyme indoleamine 2,3dioxygenase (IDO). Cancer Res 67(9): 224, 2007.

190 Dolušić E and Frédérick R: Indoleamine 2,3-dioxygenase inhibitors: a patent review (2008-2012). Expert Opin Ther Pat 23(10): 1367-1381, 2013.

191 Coombs MR, Harrison ME and Hoskin DW: Apigenin inhibits the inducible expression of programmed death ligand 1 by human and mouse mammary carcinoma cells. Cancer Lett 380(2): 424-433, 2016.

192 Miyazaki T, Moritake K, Yamada K, Hara N, Osago H, Shibata $\mathrm{T}$, Akiyama $\mathrm{Y}$ and Tsuchiya M: Indoleamine 2,3-dioxygenase as a new target for malignant glioma therapy: laboratory investigation. J Neurosurg 111(2): 230-237, 2009.

193 Hanihara M, Kawataki T, Oh-Oka K, Mitsuka K, Nakao A and Kinouchi H: Synergistic antitumor effect with indoleamine 2,3dioxygenase inhibition and temozolomide in a murine glioma model. J Neurosurg 124(6): 1594-1601, 2016.

194 Li M, Bolduc AR, Hoda MN, Gamble DN, Dolisca SB, Bolduc AK, Hoang K, Ashley C, McCall D, Rojiani AM, Maria BL, Rixe O, MacDonald TJ, Heeger PS, Mellor AL, Munn DH and Johnson TS: The indoleamine 2,3-dioxygenase pathway controls complement-dependent enhancement of chemoradiation therapy against murine glioblastoma. $\mathrm{J}$ Immunother Cancer 2(1): 21, 2014.

195 Metz R, DuHadaway JB, Kamasani U, Laury-Kleintop L, Muller AJ and Prendergast GC: Novel tryptophan catabolic enzyme IDO2 is the preferred biochemical target of the antitumor indoleamine 2,3-dioxygenase-inhibitory compound D-1-methyl-tryptophan. Cancer Res 67(15): 7082-7087, 2007.

196 Zakharia Y, Johnson TS, Colman H, Vahanian NN, Link CJ, Kennedy E, Sadek RF, Kong FM, Vender J, Munn D and Rixe O: A phase I/II study of the combination of indoximod and temozolomide for adult patients with temozolomide-refractory primary malignant brain tumors. J Clin Oncol 32(Suppl): TPS2107, 2014.
197 Colman H, Mott F, Spira AI, Johnson TS, Zakharia Y, Vahanian NN, Link CJ, Kennedy EP, Sadek RF, Munn D and Rixe O: A phase $1 b / 2$ study of the combination of the IDO pathway inhibitor indoximod and temozolomide for adult patients with temozolomide-refractory primary malignant brain tumors: Safety analysis and preliminary efficacy of the phase $1 \mathrm{~b}$ component. J Clin Oncol 33(suppl): 2070, 2015.

198 Holmgaard RB, Zamarin D, Munn DH, Wolchok JD and Allison JP: Indoleamine 2,3-dioxygenase is a critical resistance mechanism in antitumor T-cell immunotherapy targeting CTLA4. J Exp Med 210(7): 1389-402, 2013.

199 Wainwright DA, Balyasnikova IV, Chang AL, Ahmed AU, Moon KS, Auffinger B, Tobias AL, Han Y and Lesniak MS: IDO expression in brain tumors increases the recruitment of regulatory T-cells and negatively impacts survival. Clin Cancer Res 18(22): 6110-6121, 2012.

200 Mitsuka K, Kawataki T, Satoh E, Asahara T, Horikoshi T and Kinouchi H: Expression of indoleamine 2,3-dioxygenase and correlation with pathological malignancy in gliomas. Neurosurgery 72(6): 1031-1039, 2013.

201 Wainwright DA, Chang AL, Dey M, Balyasnikova IV, Kim CK, Tobias A, Cheng Y, Kim JW, Qiao J, Zhang L and Han Y: Durable therapeutic efficacy utilizing combinatorial blockade against IDO, CTLA4, and PDL1 in mice with brain tumors. Clin Cancer Res 20(20): 5290-5301, 2014.
Received February 26, 2017

Revised March 23, 2017

Accepted March 24, 2017 